\title{
"Zorba the Flashmobian": National Communities go
}

Viral

\author{
Sofia Kalogeropoulou \\ University of Otago
}

\begin{abstract}
In July 2015 a group of people gathered at the Syntagma Square in Athens, Greece, and performed the dance Zorba the Greek in a flash mob manner. The event was then uploaded on YouTube with the title The Greek soul is not in crisis: Greece hold your head high as a response to the bailout referendum (July 5, 2015) where although 61 percent of the Greek population voted NO to austerity measures, the Greek Prime Minister signed a new bailout package with the European Union implementing more severe austerity measures on Greece. In this article I explore flash mobs as novel urban phenomena that employ dance, new technological media, the element of unexpected spectacle and temporary performance site as a means of social mobilisation and political activism. In particular, I focus on the role of Zorba the Greek flash mob as a means of resistance and a medium of identity expression within the current socio-political and economic climate in Greece. Furthermore, I discuss the paradox of employing an ephemeral performative event, such as a flash mob, to project and affirm the Greek national identity-an identity that is perceived to have a diachronic value.
\end{abstract}

\section{Introduction}

Since 2010 the financial crisis in Southern Europe has had an immense impact on the life and morale of its people. In particular the severe austerity measures, capital controls, cut backs on salaries, pensions and social benefits in contrast to heavy taxation are prominent in Greece where high levels of unemployment, homelessness and poverty are the themes of everyday life (Panagiotara \& Tsintziloni, 2015). At the peak of this situation in July 2015, the Greek population participated in a bailout referendum and voted NO to austerity measures imposed by the European Commission, the International Monetary Fund and the European Central Bank. Despite the outcome of 61 percent of NO votes and disregarding the democratic nature of the referendum, the Greek Prime Minister, Alexis Tsipras, signed an agreement with the European Union and accepted a bailout package that contained larger pension cuts and tax increases than had previously been proposed (Lowen, 2015). 
A few days later, a flash mob was uploaded to YouTube with the title The Greek soul is not in crisis: Greece hold your head high (2015). The flash mob event took place in Syntagma, one of the main squares in central Athens, opposite the Greek Parliament. In a typical flash mob manner, a group of people of different ages and genders emerged from the crowd and by linking shoulder-to-shoulder, arms clasped, formed several lines one behind the other. Dressed in white T-shirts with the Greek flag as their logo, they started stepping slowly from side to side and kicking their legs in tune to the Syrtaki music that echoed all around the square. As the music accelerated gradually to a faster tempo, so did the dancing; the leg kicks became more vigorous and the dancers bobbed up and down and swayed from side to side giving the impression of a strong current. Then, they dispersed into the crowd allowing for city life to continue its mundane rhythm.

In this article I examine the flash mob event outlined above and its role in the current socio-political context in Greece. Drawing on the methodology of visual culture studies in which "all kinds of images as well as visuality itself" can be considered as framing "what we see and how we see as historically, culturally and ideologically informed" (Raun, 2016, p. 18), I analyse the YouTube clip of the flash mob. Additionally, since the study of 'culture' also includes exploring how people create and negotiate meaning around or through visual products and technologies, the comments posted online by viewers of the uploaded flash mob video provide an important source of data for analysis (Pierce, 2012; Raun, 2016). In that regard, I look at flash mobs as a means of protest and activism that mobilises the masses to respond to a particular political situation in both physical and virtual terms. I adopt the term 'political flash mob' following Flesher-Fominaya's (2011) argument that political flash mobs are distinct in their nature because they employ the element of the unexpected performance to reclaim a public space and raise public awareness, but also they are "organised at very short notice to respond to what is seen as an urgent or crisis situation" (p. 290). She highlights the important role that information and communication technologies (ICTs) play in political flash mobs to mobilise the population in repressive political contexts, even in 'consolidated democracies' where pluralism of the media is the norm (p. 290). Hence the performative element of flash mobs in combination with the efficiency of the communication technologies takes the form of guerrilla-type tactics that enable the instrumental use of flash mobs in political terms. Furthermore, I am interested in why an ephemeral event, such as a flash mob, was used to represent and affirm a concept that is perceived to have a diachronic value: the Greek national identity. 
Flash mobs as a research topic have attracted the attention of scholars in sociology, anthropology, media studies and geography. The existing literature in those fields explores the flash mob phenomenon in a variety of contexts and scope, ranging from the role of new technologies in mass mobilisation, their potential for viral advertising, their performative nature, as well as the interplay between online/offline to create new forms of sociability in public spaces (Gore, 2010; Hutter \& Hoffmann, 2011; Molnár, 2014; Rheingold, 2003; Stamenova, 2014). Noteworthy is the study of Howard Rheingold (2003) that emphasises the power of technology to orchestrate social interaction and also effectively contribute to the organisation of political protests. He accounts new media as a precondition for collective action which potentially could be used as a means of social control or resistance, as, for example, in the case of the Philippines where the head of the state Joseph Estrada lost his presidency to a protest of this nature. Hence he employs the term 'smart mobs' to describe the sophistication of the communication technologies in relation to social action (Rheingold, 2003).

In contrast, other researchers have shed light on the role of flash mobs as meaningful performative events mediated by social media to create new forms of sociability. For instance, Virág Molnár (2014) looks at flash mobs as creative and spontaneous events that break up the monotony of the everyday routine and challenge the normalised use of the public space in consumerist terms. Furthermore, she sees flash mobs as ideal vessels for social interaction in both virtual and physical space realms. Similarly, anthropologist Georgiana Gore (2010) examines the flash mob as a performative medium with dance as its centrality that effectively disrupts public order and temporarily reconfigures a public space with the potential to create new forms of sociability. However, the correlation between flash mobbing, culture and national identity has been under explored. This article looks at the synthesis of flash mobs in regard to the performance of the national body reflected in the dance and music while situated in a monumental national public space. Additionally, it examines the way ethnicity is expressed through dance in this localised and ephemeral event which then acquires a long-term virtual life for the perusal of a global audience.

The article is structured in the following order: I will begin with a brief historical background on flash mobs and a description of their characteristics in regard to technological media, public space and performance that have classified them as distinct urban performative phenomena. Through a variety of examples I will illustrate how these characteristics, marked by sociability and playfulness, 
create an effective and novel form of political activism. Then, I will discuss the meaning of the specific dance that was used in the Greek flash mob to demonstrate its historical significance in relation to the Greek identity and contextualise it in regard to the policies of the European Union during the financial crisis. I will conclude with a discussion on how flash mobs can act as new media for social organisation, action and expression of national identifications in physical and virtual spaces.

\section{Flash mobbing: Creative urban intervention or a frivolous prank?}

Flash mob is a new urban phenomenon that allows for the fusion of popular culture, temporary performance site, dance and new technological media to create new forms of sociability in local and global contexts (Gore, 2010; Shresthova, 2013). Its first appearance was in 2003 at Macy's department store in New York. The event was staged by Bill Wasik, a senior editor of the fashion magazine Harper's, who invited his friends, who in turn invited their friends via text messaging, emailing and blogging to gather at the store in order to negotiate the purchase of a rug for the free-love commune. The negotiations between the potential buyers and the sales person lasted approximately ten minutes and then they suddenly dispersed without buying the rug (Gore, 2010; Molnár, 2014; Stamenova, 2014). It was perhaps this event that set the criteria for the definition of flash mobs as "a public gathering of complete strangers organised via the internet or mobile phone, who perform a pointless act and then disperse" (Oxford English Dictionary, 2004). Since 2003 flash mobs have gained popularity and have taken their place in the global proscenium in a variety of forms, such as pillow fights, dance freezes, silent raves and zombie walks, increasingly fulfilling a particular commercial, celebratory or political purpose (Gore, 2010; Walker, 2013). Some examples include the T-mobile company advertising campaign at Liverpool Street station in London in 2009, the 13-M protest in Madrid in 2004 following the terrorist bombings, the tribute to Michael Jackson that took place in several cities around the world after his death, the campaign in Switzerland protesting against nuclear electricity power, and the list goes on (Flesher-Fominaya, 2011; Gore, 2010; Parviainen \& Pirhonen, 2013; Walker, 2013). Hence although flash mobs appear as fun, entertaining and a frivolous pastime, as Gore (2010) states, they are "rarely if ever 'pointless"” (p. 126). 
Regardless of the various types or the purpose that flash mobs aim to fulfil, they generally comply with the same motif in regard to their duration, the type of location that the event takes place in and the organisational techniques that they employ. Sophisticated technological advancements can facilitate the organisation of flash mobs via blogs, Twitter, Facebook, MySpace as well as text messaging and emails that were used in the early days of flash mobbing to mobilise people in a speedy and effective manner (Molnár, 2014). In that way, as Molnár (2014) states, "all main organisational platforms ... exploit one of the key novelties of the new media: the possibility of offering an effective one-to-many communication channel" (p. 52). There are, however, a few exceptions, such as the flash mob at the Denison University Department of Dance in the United States, where in order to avoid spoiling the element of surprise by the use of social media in the small university campus, the organisation happened in an old-fashioned way using paper copies with instructions (Bergstein-Dow, 2011). The viral messages are often sent from an anonymous account or organiser using a pseudonym and include instructions about the task or the actions of the flash mob, the date, the time and the location that the event will take place. For example, the text message that prompted more than a million citizens to gather at the Epifanio de los Santas Avenue (otherwise known as Edsa) in Manila in 2001, which led to overthrowing the president of the Philippines, said: “Go 2EDSA, Wear Blck" (Rheingold, 2003, pp. 157-58). The message in this case is brief and laconic; however, it demonstrates the simplicity of the organisational techniques and the effectiveness of media communications to reach a vast proportion of the population in a very short amount of time.

Media communications then act as a precondition for the organisation of flash mobs and their actual incarnation. However, the idea that a large or even small group of people is willing to respond to an anonymous message and participate in a flash mob has raised concerns about people's agency and mentality. Some argue that this demonstrates signs of a herd mentality with tendencies of conformist behaviour, while others claim that flash mobs are effective in shaping public discourse and allowing the population to exercise their agency (Molnár, 2014; Stamenova, 2014). As Bill Wasik (cited in Nicholson, 2005) explained when referring to the series of flash mobs that he conducted, he just sends the message but it is up to the recipients to decide whether they would like to participate or not. For instance, the Groove your Bump flash mob, organised by British charity Oxfam, entailed the gathering of a group of pregnant women who break danced on the 
South Bank of the Thames in London to draw attention to the difficulties of child birth and the lack of care facilities around the world (Gore, 2010). This example shows a rather socially sensitive and consciously active citizenship. But even when the flash mobs have an apolitical character, as in the case of a pillow fight or the silent disco, as I will show below, they can still be seen as meaningful social processes for city dwellers rather than frivolous pranksterisms or phenomena that simply reflect the narcissism of the contemporary urban youth (Molnár, 2014; Stamenova, 2014).

In their analysis of mobile clubbing, a type of flash mob where the flash mobbers listen and dance to their own music on their iPods/MP3 players while sharing the same public space, Ruud Kaulingfreks and Samantha Warren (2010) view flash mobs as representations of an inoperative community. This means that the participants in this flash mob capitalise on the city's anonymity to create new modes of social organisation in a non-hierarchical manner where everyone is a leader and a follower but without belonging to a particular named community. In that way, the community exists as a 'together-apart' concept where it congregates as a swarm (with the use of viral media) with loosely defined goals and while its members retain their individuality. Similarly, Molnár (2014) supports the idea of flash mobs-referring to them as 'just in time' communities-as platforms for new forms of sociability defined by ephemeral interactions and opportunities to "experiment with new group activities" in a fluid manner which can generate strong feelings of equality amongst participants (p. 54).

Regardless of addressing flash mobs as inoperative or just in time communities, the authors make a valuable point that although flash mobs appear to be 'playful', 'silly' and benign because their formation is underpinned by democratic principles, they have the potential to be turned into a strong force of social action (Kaulingfreks \& Warren, 2010). As such they epitomise new forms of grassroots mobilisation and social movements that deviate from the conventional forms of protest such as marches and demonstrations or even more extreme forms of violent riots as we have witnessed recently in Southern Europe in relation to the financial crisis (Thörn, Mayer, \& Thörn, 2016; Wearden, 2012). In addition, as Louisa Martin Rojo (2014) states, flash mobs are rarely censored by mass media and political parties and thus "it is possible" through them "to avoid using the dominant framework for understanding [a] political situation and to reframe the issue by creating a whole new narrative which assigns new roles and functions to the social actors" (p. 595). She attributes this to the fact that flash mobs appear 
apolitical in nature because of the performative and choreographic elements that transform the public space onto a stage.

This point leads me to discuss the affinity that flash mobs have with particular geographical locales. As strictly urban phenomena, flash mobs take place in densely and heterogeneously populated city centres and public spaces such as squares, shopping malls, parks, train or underground stations and universities (Kaulingfreks \& Warren, 2010; Molnár, 2014; Stamenova, 2014). In this way, flash mobs use the physical and symbolic landscape of the city as a theatre for an unexpected performance in order to draw attention, create interest, arouse public opinion and make socio-political statements. For example, the dancers of the Glee flash mob used the circular ground floor of a balcony-tiered architectural space in Madrid to showcase their choreography (Gore, 2010), while people in Cairo occupied the Tahrir Square to demonstrate against the current financial crisis and their political regime (Rojo, 2014). Here the first flash mob utilised the city's natural theatrical setting which is often modelled on Greek or Roman amphitheatres for purely commercial purposes, while the latter used the square as an 'agora', a place for public discourse (as in Ancient Greece) (Rojo, 2014; Stamenova, 2014). This shows the versatile and contradictory nature of flash mobs that on the one hand can reinforce the commodification of a public space while on the other hand can attempt the reterritorialization of core city spaces from an orderly capitalist configuration to a meeting point for social interaction, "decisionmaking and intervention in the governance of the community” (Rojo, 2014, p. 589).

Most importantly, it is the centrality of the performing body in the theatricalised urban space and the short duration of the performance (approximately ten minutes in length) that can achieve the impact that flash mobs strive for: public attendance and public attention. It is the performative intrusion into the public sphere that disrupts momentarily the monotony of the everyday routine of city life and simultaneously acquires a live audience by attracting the attention of passers-by. As Gore (2010) states, “The very reconfiguration, through the dancing, of the layout of public space forces attention on the performance, thus constituting a heterogeneous public into a community with a shared focus-the audience-even if only for the space of a song or two" (pp. 128-29). The element of the unexpected and the way that the body is "thrust into the public eye" in flash mobs shifts the focus of the audience and results in a cognitive impact that makes flash mobs so effective (Gore, 2010, p. 129). It is not surprising then that advertising companies around the globe employ flash mobs as a sensation 
marketing strategy for their spectacular element that goes beyond the scope of familiarity for the potential consumer (Hutter \& Hoffman, 2011). Likewise, the political movements rely on the guerrilla-type tactics of the flash mobs to arouse public opinion and trigger critical thought. Stamenova (2014), drawing on the work of Habermas, applies to flash mobs the concept of lifeworld in which people engage in two modes of discourse, the communicative and the instrumental rationality, in order to understand the social world. This means that an advertising flash mob uses instrumental rationality and encourages a consumerist approach to life. However, a flash mob that aims to distract people from their consumerist endeavour or to raise awareness about a particular social issue engages with communicative rationality. This type of rationality triggers critical thinking in the audience and also in the participants who make a conscious decision to participate in a flash mob event rather than simply follow someone's instructions.

In regard to the aim of flash mobs to challenge the status quo and question the everyday or the political through various pranks and meaningful protests, they are comparable to the avant-garde artistic movements of the Italian futurists in the 1910s, Dadaism and Surrealism in the interwar period, the Situationist International in the late 1950s, and the 1960s Happenings (Gore, 2010; Molnár, 2014; Walker, 2013). Similar to the flash mobs, the intellectuals of these radical art-movements employed the element of surprise, chaos and disorder, urban spectacle and absurdity to draw the attention of contemporary media and public. Their propagandistic goals ranged from attacking the bigotry and staleness of bourgeois art (as in the case of Dadaism), to challenging the chasm between politics and art or the capitalist ideas in regard to appropriation of the city space (as in Situationist International), or to expressing anti-war and anti-establishment sentiments as in the case of the Happenings (Molnár, 2014; Walker, 2013). However, flash mobs are distinguished as novel phenomena as they differ in the following ways: The most prominent feature is the partnership of flash mobs with the new technological media that follows an interesting looping pattern. As previously mentioned, flash mobs are organised with the aid of social media and, while they materialise in the actual physical space, they get recorded by mobile devices and uploaded to YouTube for further viewing. This counteracts the ephemerality that epitomises the flash mob events as they acquire a permanent "digital afterlife" in cyberspace where they can be seen by a wider audience (Soep cited in Shresthova, 2013, p. 3). Noteworthy here is also the multitude of audiences that the flash mobs create which include the live audience, the YouTube 
viewers around the world and the flash mobbers themselves who look at their performance online. In this regard, flash mobs can be accounted for creating diffused audiences that blur the distinction between "life and theatre, audience and performer more thoroughly than previous forms of surprise theatre did: these are performances where one crowd watches another that seconds before had been indistinguishable from it, where each crowd watches itself, and where mobsters anticipate being watched online" (Muse, 2010, p. 11). In regard to this, the impact of flash mobs transcend the ephemeral and the local of the live street theatre and enter into a permanent digital life that penetrates the global stage.

Another point of distinction between flash mobs and the avant-garde spectacles is in relation to the performative space. Unlike the avant-garde events that were mainly confined to exhibition halls or theatres, flash mobs use the city's natural landscape and soundscape, and while they disrupt the everyday routine they also become immersed into the everyday (Molnár, 2014; Muse, 2010). Furthermore, they reinstate the relationship between face-to-face social interaction, physical space and new technological media. This means that while the new media have shaped a particular narcissistic society where everyone is preoccupied with personal mobile devices to the point where face to face interactions can be scarce, flash mobs challenge that (Muse, 2010; Stamenova, 2014). Although flash mobs are the result of technological advancements that isolate people, they use these technological media to bring people together in a public space even for the length of the ten minutes that they approximately last. Hence they create an online/offline choreography, as Molnár (2014) calls it, where the two spaces, the viral and the physical, are not contested terrains but complement each other and operate in synergy to prompt social and collective interaction in public places (Nicholson, 2005). In a way, flash mobs can even be seen to provoke us to re-evaluate and reflect on the way that we use technological media.

\section{Zorba the Greek}

Having examined the character and the role of flash mobs as ephemeral urban phenomena, I will now look at the Greek flash mob that took place in Athens after the referendum in 2015 to unpack some of its elements in order to understand its role within the current socio-political and economic climate in Greece.

Zorba the Greek-the dance in the Greek flash mob-was created for the film bearing the same name which was co-produced by the Cypriot director Michalis 
Cacoyannis and the Twentieth Century-Fox Hollywood studio, in 1964. The film is an adaptation of the novel Vios kai Politeia tou Alexi Zorba (The Life and Times of Alexis Zorbas), written by Nikos Kazantzakis in 1946 (Basea, 2015). It tells the story of an intellectual, played by the actor Alan Bates, who arrives in Greece to reopen a lignite mine that he inherited on the island of Crete and to write a book on Buddha. Basil, or the boss as he is referred to in the film, hires Zorba, an uneducated local, played by Antony Quinn, to be his foreman (Basea, 2015; Jacobs, 2005). As the story unfolds, the characters in the film are developed in a contrasting manner. On the one hand, we are presented with the boss, a British intellect who operates with rationality, order and sophrosyne and his disinterest in savouring the simple pleasures of life. On the other hand, Zorba is portrayed as a free-spirited man of action who enjoys the earthy pleasures of life and has an ecstatic spontaneous will to live (Basea, 2015; Hnaraki, 2009; Zografou \& Pateraki, 2007). In sum, we are presented with the binaries of West and East, body and mind, or on a more philosophical level, the Apollonian versus Dionysian outlook on life (Bien, 1965). In the final scene of the film, the boss asks Zorba to teach him how to dance and therefore to help him connect with his corporeal side. So in the apotheosis of the film we see the two protagonists linked shoulder-to-shoulder, arms clasped, dancing Zorba the Greek, or the syrtaki as it is also known, under the blue Cretan sky.

The film is a reflection of the ambivalent state of the Greek nation at that time. After the influx of immigrants from Asia Minor in 1922, the effects of urbanisation and the Greek civil war between the partisans and the nationalists (also supported by the West) from 1946-49, Greece was going through a unification process and was in need of a medium that would give people a sense of common identity (Koliopoulos \& Veremis, 2002). And dance in combination with music could provide this. Zorba's dance, the syrtaki, is an amalgamation of syrtos, a traditional Cretan dance, and hasaposerviko, a dance from the rebetika era. As Magda Zografou and Mimina Pateraki (2007) state, this "combination had further political connotations that were purposefully put into action to balance the dualistic aspect of Greek identity" (p. 117). The first dance was in line with the official grand narrative that linked modern Greece with the Hellenic past, the foundation of Western civilisation and thought, and Christianity (Tsounis, 1995). The latter had its origins in the orient with distinct Ottoman/Turkish cultural characteristics that were often perceived as signs of an exotic otherness or backwardness. It was also loaded with negative connotations as it was associated with marginalised urban 
identities, sexuality, poverty and the underworld subculture of narcotics consumption (Holst-Warhaft, 1998). However, although this dance seemed to be jeopardising the notion of 'purity' of the Greek identity in relation to its Western heritage, the fact that it was ideologically free from the grand Hellenic narrative and that it was representing the life and feelings of the working class and the refugees was beneficial to the national project. The strata, and in particular the left wing intellectuals who aimed at distancing themselves from the West, found in rebetika a genuine expression for passion, despair, love and zest for life (Zografou \& Pateraki, 2007). Similarly, the music composed by Mikis Theodorakis was a fusion of Western symphonic music and popular folk tunes and was free from the ideological binaries that defined the political context of that period. In that way, Zorba the Greek would appeal not only to the national but to an international audience too (Zografou \& Pateraki, 2007).

Syrtaki then, as an 'invented tradition' (Hobsbawm \& Ranger, 1983), has become an iconic representation and a stereotype of the Greek identity and the Greek spirit. As Zografou and Pateraki (2007) state, regardless of the aim to reconcile the dipole identities, Zorba's dance comes across as “oriental as ever" and it has shaped or constructed the physiognomy of the modern Greek population as "one of celebration, feasting and dancing" (p. 121). It is worth mentioning here that in the film, unlike in the novel, the boss is of a British nationality while Zorba is Greek. Thus, the individual traits of the characters and their respective lifestyles have been contextualised within a particular framework of ethnic and national identifications (Basea, 2015). The British boss is emotionally contained and governed by logic but the Greek Zorba is exuberant, carefree and passionate. In this way Zorba's dance not only shaped the emotional and kinaesthetic image of the Greeks, but it marked its distinction from other nationalities. Thus, Zorba the Greek is a means of identification for the Greeks including the Greeks of the Diaspora and a cultural symbol to be recognised by the rest of the world. For instance, Demeter Tsounis (1995) asserts that in Adelaide, Australia, the Hasaposerviko or Zorba Dance is ethnically tagged as "an icon of Greek joy" (p. 99) that engenders some of the fundamental qualities of Greekness such as having fun and "asserting a strong sense of self within the collectivity of the community" ( $p$. 96).

In sum, syrtaki underpins the Greek culture where music, dance, food and drink are part of the everyday lived experience of the Greek community-a form of everyday nationalism (Kalogeropoulou, 2013). Bearing this in mind, we can explain 
how the performance of the flash mob in Athens becomes relevant to the current financial climate in Greece. The dance served to mark a distinct Greek culture and make a stand against the homogenising and technocratic approach of the European Union which strives for the integration of the European national communities based on economic factors rather than cultural ones. By implementing neoliberal policies and measures in order to create a supranational state or meet certain economic gains, it forces nations to conform to particular EU cultural norms and potentially lose their national character. It is not surprising then that the Greek lifestyle that I described earlier has been negatively stereotyped as the devil-may-care mentality or, as Maria Kouri (2014, p. 226) calls it, "the syrtaki lifestyle", which under the current financial crisis has lent itself to notions of laziness and under-productivity. This is ironic as the founding idea and principle of the European Union is to respect and preserve the national and regional cultural diversity of its member-states, a principle which is also expressed in its motto 'unity in diversity' (Schlenker, 2010).

So, as a response to the EU policies and austerity measures, the Greek population launched a series of Zorba the Greek flash mobs all around the country, including the flash mobs in Athens and in the Greek Diaspora, in order to protect their way of life and culture. The following quote by Kouri (2014) summarises the argument well:

Greek cultural elements were used as symbols of camaraderie against the crisis' domino effects affecting Europe. Dancing Syrtaki to “Zorba” music in banks and central sites around the world turned a misunderstood cultural cliché and the media-abused Greek lifeaffirming mentality to a cultural expression linking individuals to a common goal, namely the protection of social rights against domineering markets. (p. 229)

Zorba the Greek in the flash mobs then becomes a means of protest and a medium of solidarity amongst Greek people. ${ }^{i}$ It also represents a symbol of survival and offers them an orientation for the future, especially if we take into consideration that Kazantzakis wrote the novel during the German occupation years in order to address the resilience and strength of the people (Hnaraki, 2009). In that regard, the flash mobs might be considered to have a psychological impact in the community which uses historical events to draw inspiration from the past to interpret the present and find aspiration for the future. This is a concept that Tom Nairn (1997) calls "the janus face of nationalism". In addition, as I previously 
described, the participants in the flash mob were in physical contact with each other and by moving to a somewhat rhythmical synchronicity they were experiencing a "unisonality of community" (Tsounis, 1995). This outlines the psychological impact that flash mobs can have, which can also be explained in physiological terms. For example, the dancer and psychologist Brownyn Tarr explains that flash mobs make people feel more connected and raise the pain threshold for two reasons: first because of the chemical reaction that takes place in the body releasing endorphins, and secondly by performing "the same movement at the same time [it creates] the sense of connective oneness" (cited in Sample, 2015). Thus, we can expand the definition of flash mobs as "a manner in which people come into contact" and "more importantly [that] they share a collective perception of the flash mob action that connects them and gives them a group feeling" (Benschop in Stamenova, 2014, p. 10). In the case of the Zorba the Greek flash mob, this group feeling could have derived not only from the shared kinaesthetic experience, but also from a sense of embodying the nation through dance. In that sense it was a glimpse of the imagined community (Anderson, 2006) coming together as a swarm to momentarily perform their embodied identity.

In regard to efficacy, the Zorba the Greek flash mob against the European Union policies did not seem to have a successful outcome. In fact, recently, further austerity measures consisting of spending cuts, tax increases and privatisations were imposed on the Greek population by the Eurogroup (PressTV, 2016). However, the success of the Greek flash mob can be accounted in the following ways: It asserted a novel way of social organisation to mobilise the national community in a non-hierarchical manner by employing technological media in order to protest against the current political/economic situation in Greece. This grassroots mobilisation is significant in that it shapes collective action, empowers people and reflects the agency of the citizens to actively participate in the governance of their polity (Kouri, 2014). It also asserts flash mobs as novel forms of social movements that can enhance solidarity in the national community. As Wang, Akella and Bennett (2014) assert, "these social movements are processes whereby collective identity is constructed ... and can be interpreted as "WE" of social action, the process of formulating common goals, means and actions (p. 26). The flash mob in that sense was a performative resistance that aimed to protect the values of the people that are reflected in the dance and also a process in which the national "we" was affirmed. This shows that national identity is not a fabrication of the 
elite imposed on the masses, but it is also a bottom up process whereby people contribute to its construction and use it to fulfil their own means.

It was not surprising then that people organised a Zorba the Greek flash mob to draw attention, trigger public opinion and express their dissatisfaction to the Greek government's and the EU's undemocratic processes in relation to the referendum. As I previously mentioned, flash mobs are effective media in communicating a succinct message because of their unexpected performative bursts into public places that disrupt the everyday and, although they last only a few minutes, leave audience and participants alike with vivid experiences and images. In addition, the flash mob served another important role which was to draw the attention of the global community by using YouTube as a communicative channel. This intention was clearly articulated in the caption below the flash mob clip that said: "Let's make it go viral” (Aksizei kinopeisi apo olous mas, na kanei to gyro tou kosmou). And it did, as it has had 1,262,105 viewings and a significant number of posts from people all around the world who expressed feelings of ethnic pride, ethnic shame, awe and disapproval in their comments. So Zorba the Greek transitioned from ephemerality into a permanent cyberspace where it could be shared and viewed by the local and global communities and be debated, criticised or approved for the values and ideas that it represents in identity terms.

Finally, the Zorba the Greek flash mob capitalised on the most prominent public space in Greece for its performance, which was the Syntagma Square (translating into Constitution Square). The square constitutes the core of the city, physically and representationally as a tourist attraction, a meeting place for the locals and a commercial centre (Rojo, 2014). It is also where the Greek Parliament is situated-the supreme democratic institution in which all the legislation of the reforms have been debated and passed. Therefore by placing the flash mob there, it disrupted the usual flow of people and traffic and inevitably brought the issue of national identity to the fore. Most importantly, squares have always been significant physical spaces to democratic societies. It is there that marches, demonstrations, public debates and resistance take place (Rojo, 2014). Accordingly, Syntagma has been the epicentre of demonstrations since the first signs of the financial crisis in 2008, and recently prior and post referendum (Smith, Vogt, \& Tremlett, 2010). Similarly, the Greek citizens in the flash mob were reterritorialising the space and demanding justice, democracy and respect of their social rights-especially as they were dancing opposite the Greek Parliament. Nevertheless, unlike previous demonstrations and riots that often ended in 
destruction and violent clashes with the police, this protest was different as it employed dancing to the popular tunes of the syrtaki as a guerrilla-type tactic to protest against the situation (Gore, 2010; Walker, 2016). This type of resistance is significant in that it marks a shift in the political practice of the community that is underpinned by a humanitarian principle rather than institutional/political party affiliations and thus hopes that it would be more effective in challenging and changing the status quo (Rojo, 2014; Stavrides, 2012).

\section{Conclusion}

In conclusion, in this article I examined the flash mob of Zorba the Greek as a means of social protest and political activism. In a combination of the speedy efficiency of the new information and communication technologies as an organisational mode and the unexpected performative spectacle of the syrtaki in the Syntagma Square, the Greek population employed a flash mob as a guerrillatype tactic to protest against the hegemonic tendencies of the European Union. In that way the flash mob acted as a platform for collective action that brought the community together under a common goal, namely the protection of their social and political rights and their culture. So it offered an alternative approach in expressing the public opinion in regard to the austerity measures, since the outcome of the referendum was overridden and had no impact on the EU leaders. This time the Greek collectivity physically manifested itself in the flash mob to demonstrate its solidarity, determination and cultural identity through the dance.

The Zorba the Greek flash mob demonstrates many of the features of flash mobs, such as the use of the public space as a temporary performance site, its nonhierarchical mode of organisation and its ephemeral and yet long-term life in cyberspace. It also shows that flash mobs can be used for political purposes and to represent a community wider than the immediate group of its participants, i.e. the national community. In addition, the actual dance itself is under-researched in the flash mob literature. In the case of the syrtaki flash mob, it was as much the movement and the historical context of the dance as the event itself that created the meaning and significance. In the novel and the film Zorba the Greek, Zorba tells his boss: "Boss, I have never loved a man as much as you. I have hundreds of things to say, but my tongue just can't manage them. So I will dance them for you." 


\section{References}

Anderson, B. (2006). Imagined communities. London, England: Verso.

Basea, E. (2015). Zorba the Greek, Sixties exotica and a new cinema in Hollywood and Greece. Studies in European Cinema, 12(1), 60-76. doi:10.1080/17411548.2015.1015830

Bergstein-Dow, C. (2011). Dance, pop culture and community: A tale of two flash mobs. Journal of Dance Education, 11, 140-142. doi:10.1080/15290824.2011.616818

Bien, P. (1965). Zorba the Greek, Nietzsche and the Perennial predicament. The Antioch Review, 25(1), 147-163. doi:10.2307/4610670

Flesher-Fominaya, C. (2011). The Madrid bombings and popular protest: Misinformation, counter information, mobilisation and elections after ' $11-M$ '. Contemporary Social Sciences, 6(3), 289-307. doi:10.1080/21582041.2011.603910

Gore, G. (2010). Flash mob dance and the territorialisation of urban movement. Anthropological Notebooks, 16(3), 125-131.

Hnaraki, M. (2009). Speaking without words: Zorba's dance. Bulletin of the Institute of Ethnography, 1(2), 25-35.

Hobsbawm, E., \& Ranger, T. (1985). The invention of tradition. Cambridge, England: Cambridge University Press.

Holst-Warhaft, G. (1998). Rebetika: The double-descended deep songs of Greece. In W. Washabaugh (Ed.), The passion of music and dance: Body, gender and sexuality. Oxford, England: Berg.

Hutter, K., \& Hoffmann, S. (2011). Guerrilla marketing: The nature of the concept and propositions for further research. Asian Journal of Marketing, 5(2), 39-54. doi:10.3923/ajm.2011.39.54

Jacobs, A. (2005). “We're all brothers! All worm meat!": A consideration of Kazantzakis' Zorba the Greek in the quest for the just society. Contemporary Justice Review, 8(2), 229-237. doi:10.1080/10282580500082002

Kalogeropoulou, S. (2013). Greek dance and everyday nationalism in contemporary Greece. Dance Research Aotearoa, 1, 55-74. doi:10.15663\%2Fdra.v1i1.6

Kauliggfreks, R., \& Warren, S. (2010). Swarm: Flash mobs, mobile clubbing and the city. Culture and Organisation, 16(3), 211-227. doi:10.1080/14759551.2010.503498

Koliopoulos, J. S., \& Veremis, T. M. (2002). Greece: The modern sequel from 1821 to the present. London, England: Hurst \& Company.

Kouri, M. (2014). EU integration and cultural diplomacy in times of crisis: The case of Greece. The Journal of Arts Management, Law, and Society, 44, 218-233. doi: $10.1080 / 10632921.2014 .964383$

Lowen, M. (2015, July 6). Greece debt crisis: Greek voters reject bailout offer. BBC News. Retrieved from: http://www.bbc.com/news/world-europe-33403665

Molnár, V. (2014). Reframing public space through digital mobilization: Flash mobs and contemporary urban youth culture. Space and Culture, 17(1), 43-58. doi: $10.1177 / 1206331212452368$

Muse, J. H. (2010). Flash mobs and the diffusion of audience. Theater, 40(3), 9-23. doi:10.1215/01610775-2010-005

Nairn, T. (1997). Faces of nationalism: Janus revisited. London, England: Verso.

Nicholson, J. A. (2005). Flash! Mobs in the age of mobile connectivity. Fibreculture Journal, 6, 1-15.

Panagiotara, B., \& Tsitsilon, S. (2015). A shifting landscape: Contemporary Greek dance and conditions of crisis. Journal of Greek Media and Culture, 1(1), 29-45. doi:10.1386/jgmc.1.1.29_1

Parviainen, J., \& Pirhonen, A. (2013). Social movements within interfaces in urban environments: Flash mobs as kinaesthetic marketing and political campaigns. Tempere, Finland: lugYmedia.

Pierce, L. (2012). Taking it to the streets: An examination of the flash mob (Unpublished Master's thesis). Massey University, Wellington, New Zealand.

PressTV. (2016, May 23). Greek parliament passes fresh austerity measures amid public protests. Retrieved from http://www.presstv.ir/Detail/2016/05/23/466934/greek-parliamentausterity-measures-tsipras. 
Raun, T. (2016). Out online: Trans self-representation and community building on YouTube. New York, NY: Routledge.

Rheingold, H. (2003). Smart mobs: The next social revolution. Cambridge, MA: Perseus.

Rojo, L. M. (2014). Occupy: The spatial dynamics of discourse in global protest movements. Journal of Language and Politics, 13(4), 583-598. doi:10.1075/jlp.13.4.0lmar

Sample, I. (2015, October 28). Rhythm without the blues: How dance crazes makes us feel a step closer. The Guardian. Retrieved from https://www.theguardian.com/science/2015/oct/28/rhythm-without-the-blues-how-dance-crazesmake-us-feel-a-step-closer.

Schlenker, A. (2010). "Unity in diversity": The acceptance of cultural diversity and its impact on the compatibility of national and European identity. Paper in Fifth PanEuropean Conference, University of Porto, Portugal.

Shresthova, S. (2013). Bollywood dance as political participation? On flash mobs, new media, and political potential. The International Journal of Research into New Media Technologies, 1-7. doi:10.1177/1354856513486532

Smith, H., Vogt, A., \& Tremlett, G. (2012, May 18). Southern Europe fears summer of violence. The Guardian. Retrieved from https://www.guardian.co.uk/world/2012/may/18/southern-europe-fears-summer-violence

Stamenova, M. (2014). Flash mobs: Social construction of public spaces as places for sociability \& public discourse (Unpublished master's thesis). Ultrecht University, The Netherlands.

Stavrides, S. (2012). Squares in movement. South Atlantic Quarterly, 111(3), 585-596. doi:10.1215/00382876-159608

The Greek soul is not in crisis: Greece hold your head high (ELLAS Psila to Kefali), (2015, July 25). Retrieved from

https://www.facebook.com/ellas.pshla.to.kefali/videos/1610391912545126/

Thörn, H., Mayer, M., \& Thörn, C. (2016). Re-thinking urban social movements, 'riots' and uprisings: An introduction. In M. Mayers, C. Thörn, \& H. Thörn (Eds.), Urban uprisings: Challenging neoliberal urbanism in Europe. London, England: Palgrave Macmillan.

Tsounis, D. (1995). Kefi and Meraki in Rebetika Music of Adelaide: Cultural constructions of passion and expression and their link with the homeland. Yearbook for Traditional Music, 27, 90-103. doi:10.2307/768105

Walker, K. (2016, February 12). Greek farmers protesting pension reform plans clash with riot police. Euronews. Retrieved from http:/www.euronews.com/2016/02/12/greekfarmers-protesting-pension-reform-plans-clash-with-riot-police/

Walker, R. (2013). Fill/flash/memory: A history of flash mobs. Text and Performance Quarterly, 33(2), 115-132. doi:10.1080/10462937.2013.764002

Wang, C-P., Akella, D. P., \& Bennett, C. F. (2014). Flash mobs in the 21st Century: Mobile technology shapes human collective behaviour. International Journal of Business, Humanities and Technology, 4(3), 24-32.

Wearden, G. (2012, November 14). Europe's day of anti-austerity strikes and protests turn violent - as it happened. The Guardian. Retrieved from https://www.theguardian.com/business/2012/nov/14/eurozone-crisis-general-strikes-protest-dayof-action

Webster, J. (2013, April 18). How flash mob flamenco took on the banks. BBC News Magazine. Retrieved from http://www.bbc.com/news/magazine-22110887.

Zografou, M., \& Pateraki, M. (2007). The 'invisible' dimension of Zorba's Dance. International Council for Traditional Music, 39(1), 117-131.

\footnotetext{
${ }^{i}$ A similar response to the financial crisis was seen in Andalusia and Seville in Spain in 2014. The anticapitalist group Flo6x8 performed a series of flamenco flash mobs inside and outside banks to protest and raise awareness of the fragility of the economic situation in Spain. Interestingly, the reporter Jason Webster (2014) compares flamenco with the blues and Greek rebetika that, by expressing the hardship of everyday people, inevitably address politics.
} 